\title{
COLORECTAL NEOPLASMS- A STUDY OF CLINICO-MORPHOLOGICAL PATTERNS AND THEIR PROGNOSTIC VALUE IN A TERTIARY CARE CENTRE
}

\author{
Niharika Singh ${ }^{1}$ Puneet Tandon ${ }^{2}$
}

13rd Year Resident, Department of Pathology, Gandhi Medical College and Hamidia Hospital, Bhopal.

2Pathology Specialist-Class I, Department of Pathology, Gandhi Medical College and Hamidia Hospital, Bhopal.

\section{ABSTRACT}

\section{BACKGROUND}

Colorectal cancer is a formidable health problem, being second most prevalent neoplasm worldwide with 2.4 million people living with it. Incidence of CRC is higher in males (sex ratio $\mathrm{M}: \mathrm{F}=1.4 / 1$ ) and mean age of presentation being 62 yrs. As per Cancer registry, Bhopal, there are 40 - 60 cases of colorectal cancer per year with mean age of presentation being $53.27 \pm 15.9$ and $\mathrm{M}$ : $\mathrm{F}$ ratio of 1.5: 1.

We aimed at studying histomorphological features of CRC cases and correlating it with several clinical aspects to explore the ir role in patient's prognosis in our institute.

\section{MATERIALS AND METHODS}

The descriptive study encompassed 50 surgically resected primary CRC specimens and biopsies received during five years period. Tissue samples were processed and unstained $(3-\mu \mathrm{m})$ sections from formalin-fixed paraffin-embedded tumours were subjected to $\mathrm{H}$ and $\mathrm{E}$ staining. We excluded cases with benign lesions, previous use of anti-neoplastic, chemo or radiotherapy and associated with other concomitant malignant pathological conditions. The study variables were analysed by chi-square test, $\mathrm{Z}$ tests and student ' $\mathrm{t}$ ' test.

\section{RESULTS}

Mean age of presentation was 51.98 yrs.; M: F ratio was 0.9: 1 with greater predilection for lower socioeconomic status. Nonvegetarians were more commonly associated with PDAC. In our study, left-sided colon cancers and rectum cancers outnumbered right-sided cancers. Right-sided tumours mainly presented with pain abdomen, weakness and fatigue, whereas pain and per rectal bleeding being the commonest symptoms in left-sided CRCs. Majority were left-sided lesions that showed ulcerative growth patterns and were poorly differentiated $(\mathrm{p}$ value $=0.042$ ) and carried poor prognosis. Majority belonged to Dukes Stage A and B (70\%), TNM Stage: T2N0M0 (45\%), AJCC Stage II (50\%) and Astler and Coller classification Stage B2. Tumours with higher histological grading, later stages and poor differentiation carried poor prognosis.

\section{CONCLUSION}

Since correct histopathological diagnosis is directly related to prognosis, hence proper analysis of spectrum of CRC with clinicopathological correlation is the boon for good assessment of cases.

\section{KEYWORDS}

Colorectal Neoplasms; Adenocarcinoma; TNM; AJCC; Dukes; Staging; Prognosis.

HOW TO CITE THIS ARTICLE: Singh N, Tandon P. Colorectal neoplasms- a study of clinico-morphological patterns and their prognostic value in a tertiary care centre. J. Evolution Med. Dent. Sci. 2018;7(10):1216-1222, DOI: 10.14260/jemds/2018/278

\section{BACKGROUND}

Colorectal cancer usually develops slowly over a period of 10 to 20 years. ${ }^{1}$ Most begin as a non-cancerous growth called a polyp that develops on the inner lining of the colon or rectum. ${ }^{2}$ The most common kind of polyp is called an adenomatous polyp or adenoma. Adenomas arise from glandular cells, which produce mucus to lubricate the colorectum. An estimated one-third to one-half of all individuals will eventually develop one or more adenomas.3,4 Although, all adenomas have the capacity to become cancerous, fewer than $10 \%$ are estimated to progress to invasive cancer.5,6 The likelihood that an adenoma will evolve into cancer increases, as it becomes larger. ${ }^{7}$

'Financial or Other Competing Interest': None.

Submission 07-02-2018, Peer Review 20-02-2018,

Acceptance 22-02-2018, Published 05-03-2018.

Corresponding Author:

Dr. Puneet Tandon,

E-1/179, Arera Colony,

Bhopal-462016.

E-mail: drpuneettandon@yahoo.co.in

DOI: $10.14260 /$ jemds $/ 2018 / 278$

\section{(c) $(1)$}

Cancer that develops in glandular cells is called adenocarcinoma. Most colorectal cancers (approximately 96\%) are adenocarcinomas. ${ }^{8}$ Colorectal cancer (CRC) is a formidable health problem worldwide. There are 943,000 new cases of colorectal cancer per year.

It is the second most prevalent malignant neoplasm in the world (after breast cancer), and an estimated 2.4 million people have been living with this diagnosis over the last 5 years. It is the second most common in women $(5,71,000$ cases, $9.4 \%$ of all cancer cases) and the third most common cancer in men $\left(6,63,000\right.$ cases, $10.0 \%$ of all cancer cases). ${ }^{9}$ Almost, $60 \%$ of cases are encountered in developed countries. The number of CRC-related deaths is estimated to be approximately 608000 worldwide, accounting for $8 \%$ of all cancer deaths and making CRC the fourth most common cause of death due to cancer. Colon cancer ranks 8th and rectal cancer ranks 9 th among men. ${ }^{10}$ As per Cancer registry, Bhopal, there are 40 - 60 cases of colorectal cancer per year with mean age of presentation being $53.27 \pm 15.9$ and $\mathrm{M}$ : F ratio of 1.5: 1 . It is by far the most curable form of carcinoma of the gastrointestinal tract. 


\section{We Aimed at-}

- $\quad$ Studying histomorphological features of CRC cases.

- Correlating it with several clinical aspects to explore their role in patient's prognosis in our institute.

\section{MATERIALS AND METHODS}

The descriptive study was done from June 2012 to June 2017 to find the clinico-morphological patterns of colorectal cancer cases in Department of Pathology, Gandhi Medical College and Hamidia Hospital, Bhopal, Madhya Pradesh and further assessment of their prognostic value was done.

Data were collected from medical records, paraffin blocks and Colorectal carcinoma biopsies/ specimens received in Gandhi Medical College and Hamidia Hospital; surgically resected primary colorectal carcinoma specimens and biopsies from colorectal carcinomas. We excluded benign lesions of colorectal region and patients who previously received any chemo or radiotherapy.

A $3 \mathrm{~mm}$ thick tissue sections were taken from the tumour, tumour margins, lymph nodes and any other available tissue and were fixed in $10 \%$ formalin overnight at room temperature, processed and embedded in paraffin wax. Four $\mu \mathrm{m}$ sections were cut, deparaffinised and stained with $\mathrm{H}$ and E stains. Tumours are graded according to the modified WHO classification criteria of colorectal carcinoma (NOS) into low grade (Well and moderately differentiated) and high grade (poorly differentiated and undifferentiated) colorectal adenocarcinoma and Dukes Classification of Colorectal Cancers.

The study was approved by Institutional Ethics Committee of Gandhi Medical College, Bhopal (MP) with letter NO 7619-21 /MCI/IEC/2016 Dated:- 03/03/16.

Data was entered in a number of work sheets. Then data was analysed using appropriate statistical tests using SPSS 16.0. The qualitative data were expressed in terms of percentages. Comparison of the qualitative variables between groups was done using the chi-square test as well as ' $\mathrm{Z}$ ' test and for quantitative data student ' $\mathrm{t}$ ' test was applied. $\mathrm{P}$ value is considered significant if $\mathrm{p}<0.05$ and highly significant if $\mathrm{p}<0.01$. $\mathrm{Z}>1.96$ is considered significant. The qualitative data such as tumour grades, stages and types were expressed in terms of percentages and cross tabulation.

\section{RESULTS}

During study, we found that each year about $8 \%$ - $24 \%$ of CRC patients are admitted in our setup. During our study from June 2012 to June 2017, maximum influx of patients was in 2016 , i.e. $24 \%$. We have not found significant difference (pvalue- 0.664 ) in mean age of patients diagnosed with Colon carcinoma between current study (51.98 \pm 16.1 yrs.) and Cancer registry values for Central India region (53.27 \pm 15.9 years). Out of 50 cases, there were 26 women (52\%) and 24 men (48\%). The proportion of males (M) and females (F) in our study did not differ significantly. Majority of the patients in our study belonged to rural area (68\%) with low socioeconomic status (74\%). $52 \%$ of cases were vegetarian. We encountered pain abdomen (32\%) as the most common clinical complaints and rectal bleeding as the most common presenting complaint in patients with rectal carcinoma (28\%). $22 \%$ of our patient presented with change in bowel habit. However, only $4 \%$ patients with pain during defecation as the first complaint. Left-sided colorectal cancers were more common than right ones. Most common site being the rectum $(48 \%)$ followed by sigmoid colon (24\%). In rightsided lesion caecum was involved in 4 cases and ascending colon was involved in $14 \%$ of the cases followed by caecum (8\%).

Descending colon was involved in $4 \%$ of the cases and there was no involvement of transverse colon at all. Out of 50 CRC cases, we encountered 11 colon cancers with infiltrative growth pattern comprising $22 \%$ of the cases; 9 with cauliflower growth pattern which accounted for $18 \%$ cases and rest were biopsies and most of them were rectal biopsy $(44 \%)$, i.e. 22 in number. 8 were colonic biopsy (16\%). Majority of infiltrative patterns were left sided.

Histomorphological distribution pattern of CRC cases comprised mainly of WDAC (54\%). Out of 27 cases of WDAC in our study, one was well-differentiated mucus secreting adenocarcinoma. We found 10 cases with MDAC, of which one was moderately differentiated mucous secreting adenocarcinoma variant. $26 \%$ of the cases were MDAC. In our study, WDAC and MDAC were considered as low-grade CRC and encompassed 37 cases and $74 \% .20 \%$ of the cases were PDAC.

There were 13 cases of PDAC accounting for $20 \%$, of which 4 were mucinous variant, 2 of them were Signet ring cell carcinoma. There was one adenosquamous and basaloid squamous variant. PDAC was included in high grade, which was $26 \%$. Majority belonged to Dukes Stage A and B (70\%), TNM Stage: T2N0M0 (45\%), AJCC Stage II (50\%) and Astler and Coller classification Stage B2. Out of 13 PDAC, 5 had distant metastasis and two died within 3 years of follow-up.

We found maximum number of cases between 31 - $50 \mathrm{yrs}$. of age with WDAC being the most common. Mean age for WDAC in our study was $-53.36(\mathrm{SD}=12.6)$ years; mean age for PDAC was - $50(S D=18)$ years and mean age for MDAC was - $52.3(\mathrm{SD}=17)$ years. We applied student's t-test to find significance between age of the patient with which he/she presented and histological type and found no statistically significant difference in age of presentation of WDAC vs. MDAC $(\mathrm{p}$ value $=0.11)$, PDAC vs. $\mathrm{MDAC}(\mathrm{P}-\mathrm{value}=0.321)$ or WDAC vs. PDAC ( $\mathrm{p}$ value $=0.8$ ).

We found no statistically significant relation between sex and histopathological type (p-value was 0.756753). In current study, Urban and Rural populations differ significantly in the occurrence of different histological types of Colon cancer ( $p$ value $=0.009$ ).

*We found no significant difference in occurrence of particular histological type of Colon cancer between different socioeconomic status ( $\mathrm{p}$ value $=0.498$ ).

*We observed significant difference in occurrence of particular Histological type of Colon cancer among people of different dietary preference $(p$ value $=0.042$ ). People with non-vegetarian diet showed higher occurrence of PDAC than MDAC ( $p$ value $=0.04)$. However, no difference was seen in occurrence of WDAC vs. PDAC ( $p$ value $=0.298$ ) or between WDAC and MDAC (p value $=0.103)$ among people with different dietary habits.

When we studied sites of colorectal carcinoma cases in relation to histopathologic type we observed that $63 \%$ of the cases of rectal carcinoma were of WDAC type, $24 \%$ were PDAC and $13 \%$ were MDAC. $54 \%$ of the sigmoid colon cases were WDAC. MDAC and PDAC were in 23\% each. 14\% cases were of ascending colon, of which $43 \%$ belonged to PDAC and 
WDAC along with MDAC were 29\% each. Caecum had equal number of WDAC and MDAC. Descending colon had equal number of WDAC and PDAC cases.

Caecum did not differ in terms of WDAC or MDAC cases from other sites like ascending colon, descending colon and sigmoid colon, but caecum had higher proportion of MDAC cases than rectum (the $\mathrm{Z}$-value $=1.8$. The $\mathrm{p}$-value $=0.035$ ). Caecum did not differ in terms of WDAC cases from rectum.

However, Rectum did not differ significantly in MDAC cases when compared to the sites. There was no significant relationship between sites and poorly differentiated type of cancers. We did not observe any significant difference in histological types in terms of their presentation as polypoidal or ulcerative growth.

$* 57 \%$ of the lymph node positive cases in our study were poorly differentiated histological type. 29\% of them were well and $14 \%$ were moderately differentiated type of cancer. On performing tumour stage grouping of the colorectal carcinoma cases with regard to histopathologic types, we found the following results-

\section{Duke Stage vs. Histo Type Z-Test}

In study conducted by us- Stage A had significantly higher number of cases of WDAC histological type as compared to Stage B (Z-value $=3.3$. P-value $=0.00096)$ and Stage C (Zvalue $=3.7947$. $P$-value $=0.00016$ ) .

However, Stages A, B and C did not differ significantly in no. of MDAC histological type cases, $(\mathrm{Z}$-value $=0.69$. $\mathrm{P}$ value $=0.49$ ). Also, with regard to PDAC histological type, Stage $C$ had significantly higher number of cases than Stage A $(\mathrm{Z}$-value $=2.07 . \mathrm{P}$-value $=0.038)$, but the difference was not significant between cases of Stage $C$ and Stage B (Z-value= 1.58 , P-value $=0.11$ )

\section{Astler and Coller Classification Z Test}

In our study, Stage B2 had significantly higher WDAC cases than Stage A (Z-value $=3.28$, p-value $=0.0005)$, Stage B1 $(\mathrm{Z}$ value $=2.7, \mathrm{P}$-value $=0.003)$, Stage $\mathrm{C} 1(\mathrm{Z}$-value $=2.25, \mathrm{P}-$ value $=0.012)$, Stage $\mathrm{C} 2$ and $\mathrm{D} \quad(\mathrm{Z}$-value $=3.28$, $\mathrm{p}$ value $=0.0005$ ).

Similarly, Stage B2 had significantly higher cases of MDAC than Stage A, B1, C2 and D (Z-value= 2.09, p-value=0.019). However, difference in MDAC cases between Stage B2 and Stage $C$ was not significant $(Z$-value $=0.63$, $p$-value $=0.26$ ). Regarding PDAC cases, Stage C1 had significantly higher number of PDAC cases compared to all the other Stages A, B1, B2, C2 and D (Z-value $=-2.07, \mathrm{p}$-value $=0.019)$. Hence, Astler and Coller Classification does not correlate well to the histological types (prognosis).

\section{TNM Staging and Histopathological Type-Z Test}

In study conducted by us, T2N0M0 had significantly higher number of WDAC cases than Stage T2N1M0 and T3N0M0 $(Z$-value $=3.14, \mathrm{p}$-value $=0.0008)$ and $\mathrm{T} 3 \mathrm{~N} 1 \mathrm{M} 0, \mathrm{~T} 3 \mathrm{~N} 2 \mathrm{aM} 0$ and T4N1M0 (Z-value $=3.6515$, $\mathrm{p}$-value $=0.0001)$.

However, TNM stages did not significantly differ from each other in terms of MDAC and PDAC cases (Z-value= 1.5492, p-value $=0.06$ ).

\section{AJCC Staging vs. Histopathological Type- Z Test}

We found that Stage IIa was having significantly higher WDAC cases than Stage IIb, IIIa (Z-value $=3.15$, p-value $=$ 0.0008), IIIb and Stage IV (Z-value $=3.65$, p-value $=0.00013$ ). Stage IIIb had significantly higher number of MDAC cases than Stage I, IIb, IIIa and IV (Z-Score= 2.07, p-value= 0.019), but not compared to Stage IIa (Z-value $=0.63$. The $p$-value $=$ $0.26)$.

Similarly, Stage IIIa had significantly higher PDAC cases than all the other stages (Z-value $=3.16$, $p$-value $=0.0007$ ).

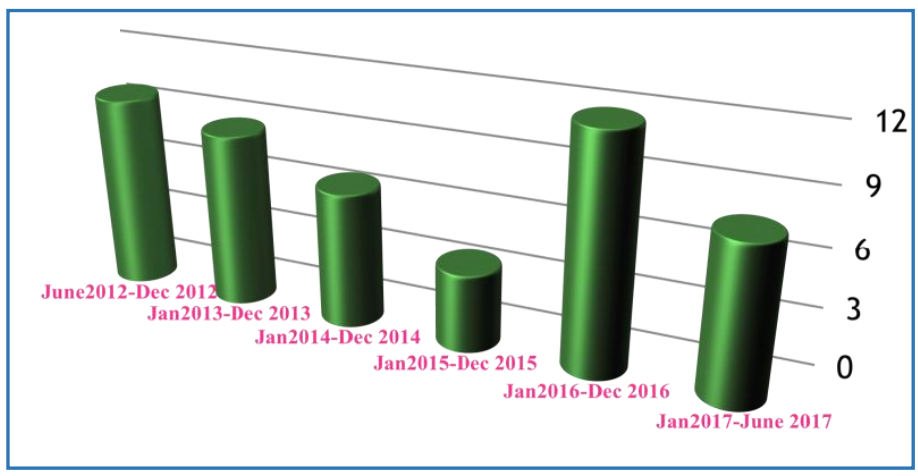

*Yearly Influx of Studied Colorectal Cases

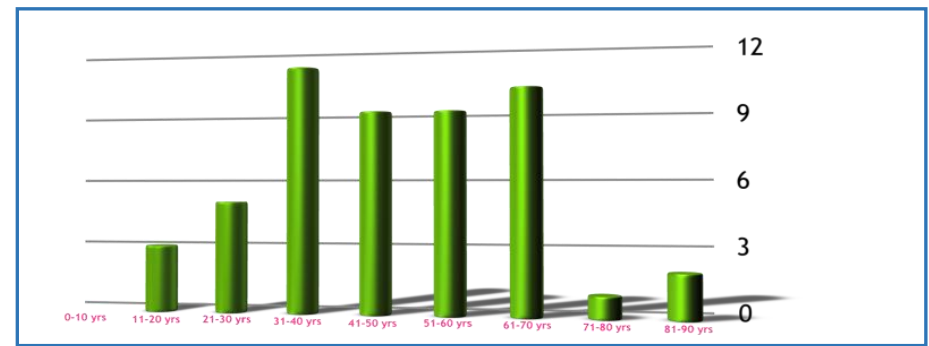

Minimum Age: 14 yrs., Maximum age: 83 yrs., Mean Age: 54.5 yrs., Mode: 70 yrs. (6) *Age Characteristics in studied Colorectal Carcinoma Cases 


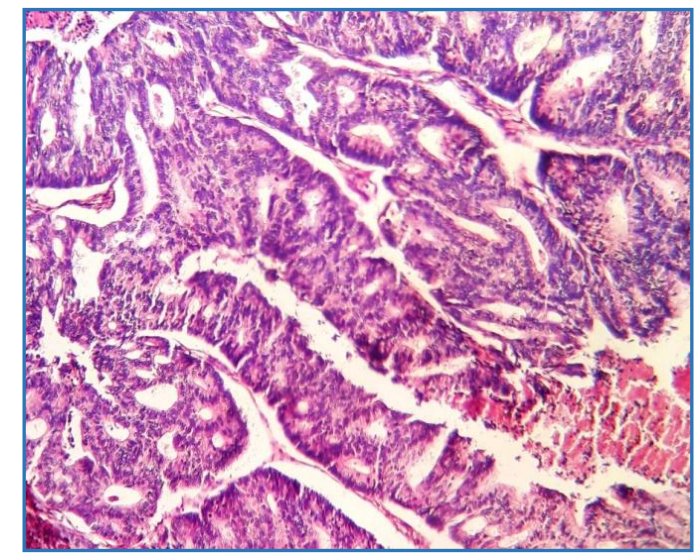

Well-Differentiated Adenocarcinoma
Rectosigmoid Region (H and E, X10)

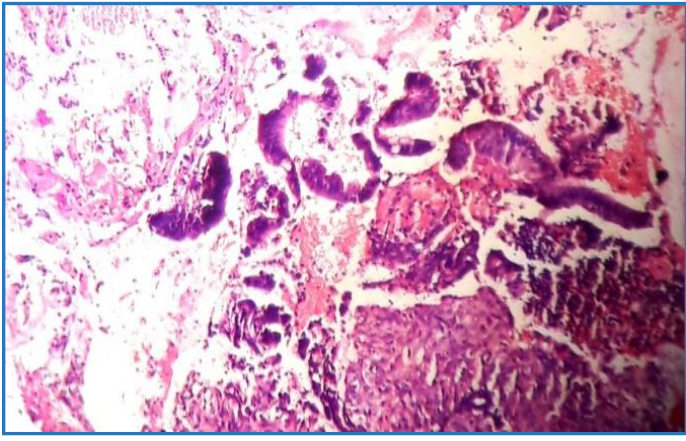

Moderately Differentiated Adenocarcinoma (H and E, X10)

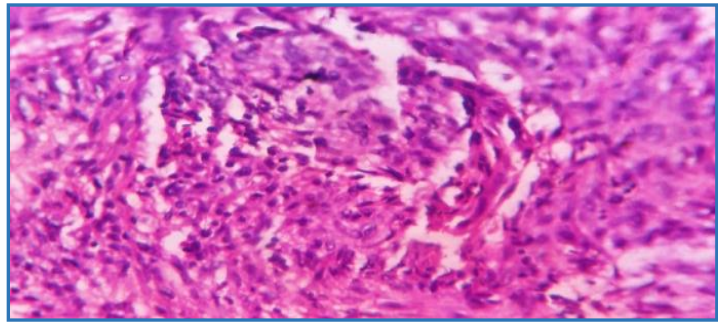

Poorly Differentiated

Adenocarcinoma (H and $E, X 40)$

\begin{tabular}{|c|c|c|c|c|c|c|}
\hline $\begin{array}{l}\text { Sr. } \\
\text { No. }\end{array}$ & $\begin{array}{l}\text { Studies } \\
\text { (Place) }\end{array}$ & Time Period & $\begin{array}{l}\text { No. of } \\
\text { Cases }\end{array}$ & Age Range (yrs.) & Mean Age & Sex \\
\hline 1 & Phillip Fleshner et al ${ }^{11}$ & 1976-1981 & 927 & $18-95$ & $68.5+/-0.5$ & $\begin{array}{l}M=52 \% \\
F=49 \% \\
M: F=1\end{array}$ \\
\hline 2 & $\begin{array}{l}\text { D. Chatter Cora et al } 12 \\
\text { New York City }\end{array}$ & 1976-1995 & 688 & $\begin{array}{c}\text { Patients were categorised into three } \\
\text { different age groups: }<45 \text {, between } \\
45 \text { and } 64 \text { years and }>/=65\end{array}$ & 60.4 & $\begin{array}{c}\mathrm{M}=47.6 \% \\
\mathrm{~F}=52.4 \% \\
\mathrm{M}: \mathrm{F}=0.9\end{array}$ \\
\hline 3 & $\begin{array}{l}\text { Musthafa Chalikandy } \\
\text { Peedikayil et al }{ }^{13}\end{array}$ & $\begin{array}{c}\text { January } 2001 \\
\text { to December } 2005\end{array}$ & 220 & $23-85$ years & 58.4 years & $\begin{array}{l}M=67.7 \% \\
F=32.3 \% \\
M: F=2.09\end{array}$ \\
\hline 4 & $\begin{array}{c}\text { Hunaldo Lima deMenezes } \\
\text { et al14 "Hospital São Paulo" } \\
\text { Brazil }\end{array}$ & $\begin{array}{l}\text { Between } 2002 \\
\quad \text { and } 2005\end{array}$ & 82 & $29-89$ & 59 years & $\begin{array}{l}\mathrm{M}=46.3 \% \\
\mathrm{~F}=53.7 \% \\
\mathrm{M}: \mathrm{F}=0.86\end{array}$ \\
\hline 5 & $\begin{array}{l}\text { Intisar Salim Pity } \\
\text { et al15 Duhok/Iraq }\end{array}$ & $\begin{array}{l}\text { January } 2007 \text { to } \\
\text { March } 2008\end{array}$ & 52 & $\begin{array}{l}20-60 \text { and } \\
\text { above } 60\end{array}$ & 63 & $\begin{array}{c}\mathrm{M}=38.5 \% \\
\mathrm{~F}=61.5 \% \\
\mathrm{M}: \mathrm{F}=0.6\end{array}$ \\
\hline 6 & Present Study & $\begin{array}{l}\text { June } 2012 \text { to } \\
\text { June } 2017\end{array}$ & 50 & $14-83$ & 51.98 & $\begin{array}{c}\mathrm{M}=48 \% \\
\mathrm{~F}=52 \% \\
\mathrm{M}: \mathrm{F}=0.92\end{array}$ \\
\hline
\end{tabular}




\begin{tabular}{|c|c|c|c|c|}
\hline Sr. No. & Studies (Place) & Time Period & No. of Cases & Socioeconomic Status \\
\hline 1 & $\begin{array}{c}\text { Hannah L Brooke } \\
\text { Et al } 16 \text { Sweden }\end{array}$ & $1993-2010$ & 82,686 & $\begin{array}{c}\text { Low socioeconomic status with more risk of rectal cancer. } \\
\text { Colon cancer had no effect. }\end{array}$ \\
\hline 2 & $\begin{array}{c}\text { Chyke A Doubeni } \\
\text { United States } 17\end{array}$ & $1995-2006$ & 506488 & Low socioeconomic status with more risk of adenocarcinoma. \\
\hline 3 & Present Study & June 2012 -2017 & 50 & Low socioeconomic status with more risk of adenocarcinoma. \\
\hline \multicolumn{4}{|c}{ Table 2. ${ }^{*}$ Comparison of Socioeconomic Status of Colorectal Cancers in Various Studies with Present Study } \\
\hline
\end{tabular}

\begin{tabular}{|c|c|c|c|c|}
\hline Sr. No. & Studies & Time Period & No. of Cases & Urban/ Rural \\
\hline 1 & Steven S Coughlin ${ }^{18}$ & 1998-2001 & $4,95,770$ & More in Urban \\
\hline 2 & Javid G et al,19 Kashmir & $2005-2006$ & 212 & More in Urban \\
\hline 3 & Sumanta Bhattacharya et al, ${ }^{20}$ North Bengal & April 2011 -March 2013 & 52 & More in Urban \\
\hline 4 & Present Study & June $2012-2017$ & 50 & More in Rural \\
\hline
\end{tabular}

\begin{tabular}{|c|c|c|c|c|}
\hline Sr. No. & Studies (Place) & Time Period & No. of Cases & Vegetarian/ Non-Vegetarian \\
\hline 1 & Orlich MJ et al ${ }^{21}$ & January 1, 2002 - December 31, 2007 & 490 & More in Non-Vegetarian \\
\hline 2 & $\begin{array}{c}\text { Sumanta Bhattacharya } \\
\text { et al, }{ }^{20} \text { North Bengal }\end{array}$ & April 2011 - March 2013 & 52 & More in Non-Vegetarian \\
\hline 3 & Present Study & June 2012 - 2017 & 50 & More in Vegetarian \\
\hline \multicolumn{2}{|r|}{ Table 4. *Comparison of Vegetarian/ Non-vegetarian Population involved in } \\
Colorectal Cancers in Various Studies with Present Study
\end{tabular}

\begin{tabular}{|c|c|c|c|c|c|c|c|}
\hline $\begin{array}{l}\text { Sr. } \\
\text { No. }\end{array}$ & $\begin{array}{l}\text { Studies } \\
\text { (Place) }\end{array}$ & $\begin{array}{l}\text { Time } \\
\text { Period }\end{array}$ & $\begin{array}{l}\text { No. of } \\
\text { Cases }\end{array}$ & Site & $\begin{array}{c}\text { Histopathological } \\
\text { Type }\end{array}$ & $\begin{array}{c}\text { Histopatholgical } \\
\text { Grade }\end{array}$ & Stage \\
\hline 1 & $\begin{array}{c}\text { Hoda M Ismail et } \\
\text { al,22 Egypt }\end{array}$ & $\begin{array}{l}1995- \\
2003\end{array}$ & 104 & $\begin{array}{l}\text { Right colon: } 42.3 \% \\
\text { Left colon: } 16.4 \% \\
\text { Rectum: } 41.3 \%\end{array}$ & $\begin{array}{c}\text { Adenocarcinoma }=75 \% \\
\text { Mucoid }=20.2 \% \\
\text { SRC }=4.8 \%\end{array}$ & $\begin{array}{c}\text { Low }=59.6 \% \\
\text { (Grade } 1+ \\
\text { Grade 2) } \\
\text { High }=40.4 \%\end{array}$ & $\begin{array}{l}\text { Dukes Stage: } \\
A-B=47.1 \% \\
C-D=52.9 \%\end{array}$ \\
\hline 2 & $\begin{array}{l}\text { Hunaldo Lima de } \\
\text { Menezes14 } \\
\text { et al “Hospital } \\
\text { São Paulo," Brazil }\end{array}$ & $\begin{array}{c}\text { Between } \\
2002 \text { and } \\
2005\end{array}$ & 82 & $\begin{array}{l}\text { Right colon: } 32.92 \% \\
\text { Left colon: } 35.37 \% \\
\text { Rectum: } 31.71 \%\end{array}$ & - & - & $\begin{array}{c}\text { TNM } \\
\text { Stage I }=12.2 \% \\
\text { Stage II }=39.0 \% \\
\text { Stage III }=31.7 \% \\
\text { Stage IV }=17.1 \% \\
\end{array}$ \\
\hline 3 & $\begin{array}{l}\text { Mihalache } \\
\text { AL et al } 23\end{array}$ & $\begin{array}{l}2004- \\
2008\end{array}$ & 120 & $\begin{array}{l}\text { Sigmoid and } \\
\text { rectum= } 72.5 \% \\
\text { Cecum and } \\
\text { Ascending colon } \\
=23.33 \% \\
\text { Transverse } \\
\text { colon }=4.16 \% \\
\end{array}$ & $\begin{array}{c}\text { WDAC }=3.33 \% \\
\text { MDAC }=75 \% \\
\text { PDAC }=15 \% \\
\text { with } \\
\text { Undifferentiated } \\
\text { form being } \\
6.66 \%\end{array}$ & $\begin{array}{c}\text { Low }=78.3 \% \\
\text { High }=21.7 \% \\
\text { Grade } 1=3.33 \% \\
\text { Grade } 2=75 \% \\
\text { Grade } 3=21.66 \%\end{array}$ & $\begin{array}{c}\text { TNM } \\
\text { Stage I= } 4.16 \% \\
\text { Stage II }=26.6 \% \\
\text { Stage III }=37.5 \% \\
\text { Stage IV }=31.6 \%\end{array}$ \\
\hline 4 & $\begin{array}{l}\text { Intisar Salim } \\
\text { Pity et al, } 15 \\
\text { Iraq }\end{array}$ & $\begin{array}{l}\text { January } \\
2007- \\
\text { March } \\
2008\end{array}$ & 52 & $\begin{array}{l}\text { Right colon: } 26.9 \% \\
\text { Left colon and } \\
\text { rectum: } 73.1 \%\end{array}$ & $\begin{array}{l}\text { WDAC and } \\
\text { MDAC }=80.8 \% \\
\text { PDAC }=19.2 \%\end{array}$ & $\begin{array}{c}\text { Low }=80.8 \% \\
\text { HIGH }=19.2 \% \\
\text { Grade } 1=49 \% \\
\text { Grade 2=18\% } \\
\text { Grade 3=33\% } \\
\end{array}$ & $\begin{array}{c}\text { TNM } \\
\text { Stage II }=71.2 \% \\
\text { Stage III }=19.2 \% \\
\text { Stage IV }=9.6 \%\end{array}$ \\
\hline 5 & $\begin{array}{c}\text { Bhagyalakshmi, } \\
\text { Vishakapatnam }^{24}\end{array}$ & $\begin{array}{l}\text { August } \\
2011- \\
\text { July } \\
2013\end{array}$ & 51 & $\begin{array}{l}\text { Right colon: } 33.3 \% \\
\text { Left colon: } 21.6 \% \\
\text { Rectum: } 45.1 \%\end{array}$ & $\begin{array}{c}\text { Adenocarcinoma }=86 \% \\
\text { Mucinous } \\
\text { carcinoma }=10 \% \\
\text { Signet ring } \\
\text { carcinoma }=4 \% \\
\end{array}$ & $\begin{array}{l}\text { Grade } 1=51 \% \\
\text { Grade } 2=25 \% \\
\text { Grade 3 }=24 \%\end{array}$ & - \\
\hline 6 & $\begin{array}{l}\text { Present } \\
\text { Study }\end{array}$ & $\begin{array}{l}\text { June } \\
2012 \\
-2017\end{array}$ & 50 & $\begin{array}{l}\text { Right colon: } 24 \% \\
\text { Left colon: } 28 \% \\
\text { Rectum: } 48 \%\end{array}$ & $\begin{array}{c}\text { WDAC }=49 \% \\
\mathrm{MDAC}=18 \% \\
\mathrm{PDAC}=20 \% \\
* \mathrm{SRC}=4 \% \\
* \text { Mucinous } \\
\text { carcinoma }=9 \%\end{array}$ & $\begin{array}{c}\text { Low }=74 \% \\
\text { High }=26 \% \\
\text { Grade } 1=49 \% \\
\text { Grade } 2=18 \% \\
\text { Grade } 3=33 \%\end{array}$ & $\begin{array}{c}\text { TNM } \\
\text { Stage I= 5.0\% } \\
\text { Stage II }=50.0 \% \\
\text { Stage III }=45.0 \% \\
\text { Dukes Stage: } \\
\text { A-B }=70.0 \% \\
\text { C-D }=30.0 \% \\
\end{array}$ \\
\hline & & 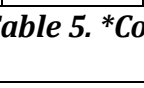 & ric & jices merved, & with Present Study & and Stages & \\
\hline
\end{tabular}

\section{DISCUSSION}

Table 1 shows that wide age distribution was noted for colorectal cancer patient in most of the study. The mean age of patients in our study was $51.98 \pm 16.16$ years. Our findings are comparable to the other mentioned studies. Male: Female ratio in our study was $0.92: 1$. 
It was closest to D Chatter Cora et $\mathrm{al}^{12}$ (1976 - 1995) and Hunaldo Lima de Menezes et al14 "Hospital São Paulo" Brazil (2002 - 2005).

The present study like Chyke A Doubeni ${ }^{17}$ (1995 - 2006) shows that low socioeconomic status had greater predilection for colorectal adenocarcinoma (Table 2).

The present study contradicted above studies and was more in rural areas and vegetarians (Table 3, 4). Since our sample size was small and most of the patients belonged to low socioeconomic status with poor dietary habit, which is itself a risk of CRC. Dr. Laurentiu Mogoanta and Liliana Nita-Stefanescu et al $^{25}$ conducted study on 163 specimens in 2013 observed a statistically significant increased risk in patients with poor diet $(\mathrm{RR}=6.83$, CI 95\%= 3.16 to 11.21), which further supports our explanation. Study conducted by Sanjay Raina et al 26 in Jammu shows rectal carcinoma comprised $50 \%$ of the total colorectal carcinoma. Sigmoid carcinoma constituted $23 \%$ of the total number of cases. Pain and per rectal bleeding being the commonest symptoms. Right-sided tumours mainly presented with anorexia, significant weight loss, fatigue and symptoms of anaemia. In present study, most common clinical complaints with which patients presented was pain abdomen, which accounted for about 32\%. However, patients with rectal carcinoma presented with mostly rectal bleeding as a presenting complaint which is $28 \%$, and abdominal pain and rectal bleeding were the most common symptoms. Rightsided tumours mainly presented with pain abdomen, weakness and fatigue which shows results similar to above study.

In our study left-sided colon cancers and rectum cancers outnumbered right-sided cancers, which is comparable to most of the studies in (Table 5).

Study conducted by Carolyn C Compton et al27 (2003) showed that tumours in the proximal or right colon usually appear grossly as polypoid or fungating exophytic masses. By contrast, tumours involving the distal or left colon are more commonly ulcerative lesions that produce an "apple-core" or "napkin-ring" appearance, which was consistent with present study.

Study conducted by Mihalache AL et al ${ }^{23}$ (2004 - 2008), most tumours were infiltrating, ulcerated (46.66\%) followed by infiltrating-stenosed (29.16\%) and protrusive (24.18\%).

In the present study, 55\% were ulcerative and $45 \%$ were proliferative polypoidal type. Out of 9 polypoid growth, 5 were found in ascending colon and 3 in caecum. However, 1 cauliflower growth pattern was found in sigmoid colon, which is not a usual growth pattern. As far as ulcerative growth pattern is considered, there were 11 ulcerative/infiltrative pattern and out of them 7 were in sigmoid colon, 2 in rectum, 1 in descending colon and 1 in ascending colon where polypoid pattern is the usual finding.

In our study, the majority of the cases were low grade, i.e. well-differentiated adenocarcinoma and moderatelydifferentiated adenocarcinoma outnumbered high grade, poorly differentiated adenocarcinoma (Table 5).

In study conducted by Hoda M Ismail et al22 (1995 - 2003) Egypt showed $47.1 \%$ cases with Dukes A and B and 59.6\% with low grade. However, in present study $70 \%$ of the cases belonged to Dukes A and B and $74 \%$ were low grade and it is similar to that conducted by Uzma Nabi et al ${ }^{28}$ in 2008 on 50 patients itself.
The present study like Hunaldo Lima de Menezes ${ }^{14}$ et al "Hospital São Paulo" Brazil (2002 - 2005) and Intisar Salim Pity et al ${ }^{15}$ (Jan 2007 - March 2008) Iraq study shows increased number of CRC in Stage II. The present study like Joana Sofia Gomes Pestana et al,29 Braga, Portugal who evaluated a sample of 512 patients from January 1st, 2005 to January 1st, 2010, through a comparative clinical, pathological and survival analysis of patients under and over 45 years old shows absence of relationship between age and histopathological grade of tumour. As per study conducted by JS Quirt et al,30 Ontario from 2002 - 2008 stage of disease and histologic grade did not vary by sex which is consistent with our study.

Safaee A et al,31 Iran conducted study on 1127 patients with CRC for 5 years duration and found that higher tumour grade, stages and less differentiated tumour carries poor prognosis. Similar results were found in the present study. Dukes staging is very important in determining the prognosis of disease. Present study shows no association between clinical parameters like age and sex of cases with histopathological types and grading of tumours. However, we found significant difference in occurrence of particular Histological type of Colon cancer among people of different dietary preference. People with non-vegetarian diet showed higher occurrence of poorly differentiated adenocarcinoma and higher mortality rates as compared to vegetarians. As far as analysis of pathological findings is considered we found no relation between site of tumour, its growth pattern and histopathological types.

Various staging system classification showed more number of well-differentiated cases in earlier stages and poorly differentiated carcinoma cases in later stages. However, we found no statistical significance between them. Tumours with higher histological grading, later stages and poor differentiation carried poor prognosis.

\section{CONCLUSION}

Correct histopathological diagnosis is directly related to prognosis, i.e. poorly differentiated cancers are associated with poor prognosis. Hence, the proper analysis of spectrum of CRC with clinico-pathological correlation is boon for good assessment of cases. We recommend meta-analysis studies to further evaluate the clinical importance of our findings with a more number of colorectal cancer cases.

\section{REFERENCES}

[1] Winawer SJ, Zauber AG. The advanced adenoma as the primary target of screening. Gastrointest Endosc Clin N Am 2002;12(1):1-9.

[2] Stryker SJ, Wolff BG, Culp CE, et al. Natural history of untreated colonic polyps. Gastroenterology 1987;93(5):1009-13.

[3] Bond JH. Polyp guideline: diagnosis, treatment and surveillance for patients with colorectal polyps. Practice Parameters Committee of the American College of Gastroenterology. Am J Gastroenterol 2000;95(11):3053-63.

[4] Schatzkin A, Freedman LS, Dawsey SM, et al. Interpreting precursor studies: what polyp trials tell us about large-bowel cancer. J Natl Cancer Inst 1994;86(14):1053-7. 
[5] Levine JS, Ahnen DJ. Clinical practice. Adenomatous polyps of the colon. N Engl J Med 2006;355(24):25517.

[6] Risio M. The natural history of adenomas. Best Pract Res Clin Gastroenterol 2010;24(3):271-80.

[7] Pickhardt PJ, Kim DH, Pooler BD, et al. Assessment of volumetric growth rates of small colorectal polyps with CT colonography: a longitudinal study of natural history. Lancet Oncol 2013;14(8):711-20.

[8] Stewart SL, Wike JM, Kato I, et al. A population-based study of colorectal cancer histology in the United States, 1998-2001. Cancer 2006;107(Suppl 5):112841.

[9] GLOBOCAN 2008. http://globocan.iarc.fr/factsheets/cancers/colorectal. asp 2008.

[10] NCRP. Three-year report of the population based cancer registries- 2009-2011. National cancer registry programme, Indian council of medical research (ICMR), Bangalore, India, 2013.

[11] Fleshner P, Slater G, Aufses AH. Age and sex distribution of patients with colorectal cancer. Dis Colon Rectum 1989;32(2):107-11. https://doi.org/10.1007/BF02553821

[12] Chattar-Cora D, Onime GD, Coppa GF, et al. Anatomic, age and sex distribution of colorectal cancer in a New York City Hispanic population. Journal of the National Medical Association 1998;90(1):19-24.

[13] Peedikayil MC, Nair P, Seena SM, et al. Colorectal cancer distribution in 220 Indian patients undergoing colonoscopy. Indian J Gastroenterol 2009;28(6):212-5.

[14] De Menezes HL, Jucá MJ, de A. Gomes EG, et al. Analysis of the immunohistochemical expressions of p53, bcl-2 and Ki-67 in colorectal adenocarcinoma and their correlations with the prognostic factors. Arq Gastroenterol 2010;47(2):141-7.

[15] Pity IS, Arif SH, Hadji DA. Angiogenesis, p53 and Bcl2 in colorectal carcinoma. International Journal of Advancements in Research \& Technology 2013;2(3):18.

[16] Brooke HL, Talbäck M, Martling A, et al. Socioeconomic position and incidence of colorectal cancer in the Swedish population. Cancer Epidemiol 2016;40:18895.

[17] Doubeni CA, Laiyemo AO, Major JM, et al. Socioeconomic status and the risk of colorectal cancer: an analysis of more than a half million adults in the NIH-AARP Diet and Health Study. Cancer 2012;118(14):3636-44..

[18] Coughlin SS, Richards TB, Thompson T, et al. Rural/non-rural differences in colorectal cancer incidence in the United States, 1998-2001. Cancer 2006;107(Suppl 5):1181-8.
[19] Javid G, Zargar SA, Rather S, et al. Incidence of colorectal cancer in Kashmir valley, India. Indian J Gastroenterol 2011;30(1):7-11.

[20] Bhattacharya S, Bhattacharya S, Basu R, et al. Colorectal cancer: a study of risk factors in a tertiary care hospital of North Bengal. Journal of Clinical and Diagnostic Research JCDR 2014;8(11):FC08-FC10.

[21] Orlich MJ, Singh PN, Sabaté J, et al. Vegetarian dietary patterns and the risk of colorectal cancers. JAMA Internal Medicine 2015;175(5):767-76.

[22] Ismail HM, El-Baradie $\mathrm{M}$, Moneer $\mathrm{M}$, et al. Clinicopathological and prognostic significance of p53, Bcl-2 and Her-2/neu protein markers in colorectal cancer using tissue microarray. Journal of the Egyptian National Cancer Institute 2007;19(1):3-14.

[23] Mihalache AL, Rogoveanu I. Immunohistochemical study in colon cancer patients. Current Health Science Journal 2011;37:116-8. chsjournal.org

[24] Bhagyalakshmi A, Sreelekha A, KasiBabu A, et al. Ki-67 proliferation index and clinicopathological patterns in colorectal carcinomas. J Clin Sci Res 2015;4:119-28. http://dx. doi.org/10.15380/2277-5706.JCSR.14.039.

[25] Mogoantă L, Niță-Ștefănescu L (Streba). Clinical, histological and immunohistochemical study of colorectal carcinoma. University of Medicine and Pharmacy of Craiova, Doctoral Thesis Craiova 2013.

[26] Raina S, Jad B, Azad T, et al. Symptomatic correlation with site of colorectal cancer. GMC, Jammu, India. IOSR Journal of Dental and Medical Sciences (IOSR-JDMS) 2015;14(11): Ver. VIII, p. 93-7.

[27] Compton CC. Colorectal carcinoma: diagnostic, prognostic and molecular features. Modern Pathology 2003;16(4):376-88.

[28] Nabi U, Nagi AH, Sami W. Ki-67 proliferating index and histological grade, type and stage of colorectal carcinoma. Journal of Ayub Medical College, Abbottabad. JAMC 2008;20(4):44-8.

[29] Pestana JSG, Martins SFF. Colorectal cancer: comparative analysis of clinical and pathological characteristics in patients aged above and below 45 years of age and impact on prognosis. Câncer colorretal: análise comparativa das características clínicas e anatomopatológicas em doentes com idade superior e inferior a 45 anos de idade e impacto no prognóstico (Portuguese). J of Coloproctology (RIO J) 2016;36(4):196-201.

[30] Quirt JS, Nanji S, Wei X, et al. Is there a sex effect in colon cancer? Disease characteristics, management and outcomes in routine clinical practice. Current Oncology 2017;24(1):e15-e23.

[31] Safaee A, Moghimidehkordi B, Fatemi SR, et al. Pathology and prognosis of colorectal cancer. MRIJCP 2009;3:137-41. 